\title{
TRUTHFULNESS IN ACCOUNTING: HOW TO DISCRIMINATE ACCOUNTING MANIPULATORS FROM NON-MANIPULATORS
}

\author{
Alina Beattrice Vladu, Babes-Bolyai University, beattrice.vladu@econ.ubbcluj.ro \\ Oriol Amat, Universitat Pompeu Fabra, oriol.amat@upf.edu
}

Dan Dacian Cuzdriorean, Babes-Bolyai University, dan.cuzdriorean@econ.ubbcluj.ro

\begin{abstract}
Preparers of accounting information are in a position to manipulate the view of economic reality presented in this information to interested parties. These manipulations can be regarded as morally reprehensible because they are not fair to users, they involve an unjust exercise of power, and they tend to weaken the authority of accounting regulators.

This paper develops a model for detecting earning manipulators using financial statements ratios in a sample of Spanish listed companies. Our results provide evidence that accounting data can be extremely useful in detecting manipulators. This approach can be used by a large category of users of accounting information among them we can cite the stock exchange supervisors or investing professionals.
\end{abstract}

\section{Key Words:}

accounting ethics, accounting manipulation, accounting users, earnings management, financial reporting

\section{JEL codes:}

M1-Business Administration

\section{Area of Research:}

Finance and Accounting 


\section{Introduction}

Accounting information is used by interested parties to assess the performance of managers and to make economic decisions. Among the large variety of accounting users we can cite shareholders, bank analysts, investing professionals and the stock exchange supervisors who promote the optimal functioning of the markets and the delivery of high quality accounting information. However, accounting information may be deliberately distorted by the activities of financial statement preparers who wish to alter the content of the data being transmitted. This opportunistic behavior found in the arena of financial reporting, has been a concern for many years, since managers may have incentives to make decisions in their own interest, in the detriment of the firm`s owners (Fama, 1980; Fama and Jensen, 1983; Badertscher, 2011; Feng et al., 2011). The roots for such demarches can be found in the agency problem (Jensen and Meckling, 1976), when a principal hires an agent and the two may not have the same interests.

The past financial crisis has also generated an increased interest regarding opportunistic behavior of managers (Horton et al., 2013) while in the light of previous accounting scandalsquestions regarding if fairness have a place in business continues to spring (Rubin, 2012).

In recent years there has been a mushrooming of papers approaching different aspects of business ethics. In this regard, truthfulness as research subject was more and more approached by regulators, business schools, academicians, and media. Given the broader themes of business ethics covered in a range of established textbooks, the time is opportune for focusing on ethical issues in accounting.

The goal of this paper is to inform the debate on ethics of earnings management by examining empirically whether those practices are employed by managers using a specific 
code-law context (i.e. Spain). What makes those examined practices scandalous is not only their violation of investor protection laws but their clash with general accepted social norms or good practices (Ball, 2009). In this respect empirical analysis of financial reporting is beneficial, if no other reason than to help increase awareness and ethical behavior.

Regarded as a problem that "need of immediate remedial action" (Dechow and Skinner, 2000), earnings management practices once discovered a lax of ethics is coming to light (Lucas, 2004; Bush, 2002). In this paper the earnings management problem is regarded from a positive view (Donaldson and Prestor, 1995), exploring how companies reacts or do towards ethics. The central idea behind it is simple: if companies engage in earnings management practices, their attitude towards ethicality is not severe, and vice-versa. We also, accept the fact that in their pursuit for creating the perfect image on the market is possible that managers often apply the type of reasoning expounded in utilitarian rather than in deontological theories of ethics. In this regard, utilitarianism is often used and does not require any moral considerations (Williams, 1985, p.75) while all is permitted, given particular circumstances (MacIntyre, 1981, p.14-15).

Further is also important to bring into discussion which type of earnings management we refer to. Approaching three types of earnings management practices, Ronen and Yaari (2008) classified those practices in terms of their perceived transparency and intended purposes in: gray, white and black. Until this moment the effect of earnings management on the value of the firm and related issues of financial based incentives for engaging in manipulative practices has been widely examined in the accounting literature, while all those three types were examined (e.g., Healy 1985; Dechowet al., 1995; 1996; Daset al., 2009).

This paper is concerned with grey earnings management (in the view of Ronen and Yaari, 2008), where managers tend to choose an accounting treatment that is either opportunistic (maximizing their utility only) or economically efficient. Those grey earnings 
management are our focus since those have the potential to raise ethical issues (Davis-Friday and Frecka, 2002). Above all those gray earnings management practices refers to opportunities to exploit judgment and estimation bias (i.e. estimation of uncollectible receivables or ability, intent to refinance short-term debt or existence of significant right of return for sales); opportunities to exploit norms latitude or absence or relevant accounting regulations (i.e. conforming to the letter of a norm while concealing the substance of a transaction; biased interpretation of certain norms; biased disclosures) oropportunities to obscure the substance of related party transactions (i.e. lease-back transactions; fair value estimations; below-market borrowing by related parties).

Moreover, our study regards accounting manipulations as an obstacle for representational faithfulness and a potential factor for destabilization of companies. In this regard this particular paper is concerned mainly of the negative side of accounting manipulation practices (Gong et al., 2008) and the lack of truthfulness, similar to other papersdeveloping various models used for detecting manipulative accounts and assess their magnitude (Dechow, et al. 1995, 2012).

Taking into account above arguments this paper will try to develop a model for detecting earning manipulators using financial statements ratios. Accordingly to Altman (1968), academicians seem to move towards the elimination of ratio analysis as an analytical technique used in assessing the performance of the business enterprise. Widely used by practitioners, ratio analysis is abandoned by scholars worldwide in their attempt to develop more and more sophisticated tools to assess the effects of opportunistic behavior of managers. Similarly like Beneish (1999) we tried to follow a more traditional path to uncover earnings management practices using ratio analysis combined with a multiple discriminant statistical methodology. The prediction of manipulative behavior of Spanish companies is used as an illustrative case. 
We have conducted our tests using a sample of listed companies that manipulated their earnings and available companies listed on The Spanish Stock Exchange that were known as following the "good practices" in the period 2005-2012.

To sum up, our paper extends the literature of ratio analysis combined with rigorous statistical technique used in the context of manipulative behavior by presenting a model to distinguish manipulated from non-manipulated reporting.

The rest of the paper is structured as follows. We continue with a review of the ethics of accounting manipulations. In section three we review the existing literature, and then we go on to the methodology employed in the fourth section. This section is followed by the sample set construction. Section six discusses our empirical evidence. The paper ends with our main conclusions, summarizes the findings of our study while emphasizing the potential of traditional ratio analysis by discussing its practical decision-making situations and its potential benefits for the users of accounting information. The limits of our research are presented as well the directions for future research.

\section{The ethics of accounting manipulations}

The ethics of accounts manipulation have been widely approached in the accounting literature over the last years (e.g., Schipper, 1989; Bruns and Merchant, 1990; Merchant and Rockness, 1994; Parfet, 2000; Ronen and Yaari 2008). Involvingpreparers in an opportunistic behavior that alters accounting disclosures so as to create the view of reality that they wish to communicate to users of the financial statements, accounts manipulation is a topic of high interest. Examining this research area, truthfulness arise as prime qualitative characteristics that ensure the usefulness to the users of accounting information. 
In this respect ethics and truth are placed in the context of human relationships (Mele, 2009), where both must provide a normative blueprint for the future while for both has to be consciously striven for rather than being something to be found. In the light of previous accounting scandals the quality of communicative relations between individuals should be treated with caution. Today`s business environment is trying to grapple with a painful past of economic scandals, fraud, abuse of rules and principles, cases where the trust between individuals was affected.On the other hand, if communication and thoughts if to be taken as objective they must respond to the reality.In this respect, individuals' thoughts about the economic reality are becoming norms partially linked on how the world is.

Defined as psychological projections onto the world, norms have the potential to help individuals in guiding the recent defense of ethics and truthfulness in the economic environment. In this regard the appealing normativity of truth can help individuals and society to act in such a way as to commit to maxim. Since principles gave birth to normativity, a virtuous person must be able to assess permanently what actions are correct in given circumstance and what actions are not. Following this idea, a virtuous person is capable of following the correct and general accepted practices and to deduce what must be done in certain circumstances. Based on the above, truth becomes unavoidable as having normative consequences, and under this aegis every manager of a company for instance should be responsive to truth evaluation as correct or incorrect when assessing its action, arguing that the normativity of meaning can mean further the normativity of action.

Truthfulness, even if approached extensively in philosophy and economics, is an appealing concept with various nuances, that depends on the individual's concern with ethics, morality, and their commitment with which they perform their tasks.

A particular concern about the contemporary business practice is the extent to which some stakeholders have limited knowledge about the affairs of the company. One particular 
aspect of business ethics is the high information asymmetry between management and the users of accounting information, where usually the first has information that it keeps from other side, or simply the information disclosed is not presented according to economic reality. Those above concerns were identified when the main techniques of accounts manipulation were documented around the world. In this regard five categories of accounting manipulations were documented in the literature, as following:

(1) Sometimes the accounting rules allow a company to choose between different accounting methods (Schipper, 1989; Apellaniz and Labrador, 1995). A company can therefore choose the accounting policy that gives their preferred image.

(2) Certain entries in the accounts involve an unavoidable degree of estimation, judgment, and prediction (He and Yang, 2014). This offers business executives the opportunity to use a pessimistic or an optimistic view in preparing financial statements.

(3) Real transactions can also be timed so as to give the desired impression in the accounts. Managers are free to choose in which year the transaction is performed (Ewert and Wagenhofer, 2005; Huang et al., 2008).

(4) Real transactions can be accounted at an artificial value (Gunny, 2010).

(5) Artificial transactions can be entered. This is achieved, for example, by entering into two or more related transactions with an obliging third party, normally a bank.

Some of these categories are clearly illegal, especially the last two, but all of them have long been recognized as a critical ethical issue for the accounting profession. The notion of earnings management is especially relevant, as it is the personal code of ethics that ultimately origins this behavior (Beaudoin et al., 2014; Marsh, 2013), independently of the gender of the manager (Sun et al., 2011). Nevertheless, researchers do not agree about the approval of the use of earnings management. 
On one side, some scholars view these practices as unethical (i.e. Johnson et al., 2012; Huang et al., 2008; Vinciguerra and O'Reilly-Allen, 2004; Kaplan, 2001) as it makes unclear the real firm value and erodes trust between shareholders and managers. There are scholars who regard earnings management behavior as being against the principle of justice (Rawls, 1972); as immoral (Solomon, 1993); or as intolerable (i.e. Loomis, 1999; Grant et al., 2000) because it harms the quality of financial reporting. In this respect, Perols et al. (2012) in a research that describes the antecedents of fraud documented that firms that previously engaged in accounting manipulations practices are more likely to commit fraud in the future. For example, in 1998, the former Chairman of the Securities and Exchanges Commission (SEC), Arthur Levitt put the accounting profession on notice that those who were operating in the grey area between legitimacy and fraud were poisoning the financial reporting process. Mr. Levitt pointed out that he was "concerned that the motivation to meet Wall Street earnings expectations may be overriding common sense business practices" and that too many corporate managers, auditors, and analysts were "participants in a game of nods and winks". For Mr. Levitt, such practices eroded the quality of earnings, and therefore, the quality of financial reporting. Because of that manipulation "integrity may be losing out to illusion" (Levitt, 1998).

As Mr. Levitt pointed out, the pursuit of meeting market expectation could lead to unethical and fraudulent practices. The severity of accounting manipulations has come under the public scrutiny after a succession of accounting scandals like Enron or WorldCom in 2000. These companies were using their discretion to mislead outsiders through their financial reporting (Hsiang-Lin et al., 2008). More recently these situations happened again in cases like Lehman Brothers in 2008.

On the other side, other academics find some of the earnings management practices acceptable (i.e. Dye, 1998; Graham et al., 2005) as a technique that managers use to meet the 
stakeholders demand for maximizing the value of the company. Some scholars suggest usefulness in earnings management practices (Lin et al., 2012; Parfet, 2000; Dobson, 1999). The ones accepting earnings management practices as being ethical regard this issue from a utilitarian perspective and bring into attention questions that at least at this moment do not share a common answer: Can income smoothing be acceptable when used for the purpose of reducing information asymmetry with respect to long-term profitability? Can earnings management be acceptable when is used only with the purpose to prevent violations of debt covenants? Would receivers of accounting information consent to earnings management if it serves to a good purpose of the company? Would they consent to earnings management even if this demarche will place them naturally in the arena of the deceived? Would managers engage in earnings management practices even if this will harm the image of the company on long run but prevent harming it on short run?

Revsine (1991) discusses the 'selective financial misrepresentation hypotheses. He considers the problem in relation to both managers and shareholders, and argues that each can draw benefits from loosely drafted accounting standards that permit latitude in determining the timing of income. Shareholders can benefit from the fact that managers are able to manipulate earnings to 'smooth' income since this may decreases the apparent volatility of earnings and so increases the value of their shares. The fact that this involves deliberate manipulation and deceit is to be overlooked. Shareholders in this view become unwitting accessories to manipulation, but the agency theoretical supposition is that such behavior is inevitable given the conflict inherent in agency relationships. Prior research suggest that both incentives and ethical issues influence earnings management (i.e. Chung et al., 2005; Greenfield et al., 2008; Kaplan, 2001) and that earnings management for self-interested purposes are perceived as less ethical than earnings management for the benefit of the company (Kaplan, 2001; Merchant and Rockness, 1994). 
As stated above, most of the scholars regard earnings management as a logical result of the flexibility of the accounting rules, allowing managers to choose the option that maximize the shareholder value. In that direction, Parfet (2000) distinguishes between good and bad earnings management practices. Good earnings management happens when executives generate stable financial performance by acceptable voluntary business decisions. Bad earnings management practices happen when managers generate artificial accounting entries or extend estimates beyond realistic limits. A defense of creative accounting behavior can be made which rests upon agency and positive accounting theories.

Regarding organizations, Elias (2002) found a positive relationship between social responsibility and, focus on long-term gains, the ethical perception of earnings management and a negative relationship between focus on short-term gains and the ethical perception of this practice. Yongtao and Andersen (2011) found that more socially responsible firms have less earnings management activity and a better financial reporting quality and Choi and Jinhan (2011) found that commitment to business ethics has perpetuating effects on future financial reporting quality. In that sense, Shafer (2013) found that perceptions of the organization ethical climate were significantly associated with belief in the importance of corporate ethics responsibility, which also was associated with accountants' ethical judgments and behavioral intentions regarding accounting and earnings manipulation.

Being an area where most of the conflicting views seem to gather, earnings management comprises a large variety of discussions. From all the discussions approached in its arena, nothing is more interesting and challenging than the acceptance of earnings management practices from ethical point of view. In this regard, ideas and research questions spring daily, and daily remain without a straightforward answer. Based on the fact that stakeholders have conflicting interests, earnings management will continue to remain a grey area of confronting ideas. Summarizing the above, the opinions on the acceptability of 
accounting manipulation vary, but even so very often they are perceived as reprehensible. In this sense Merchant and Rockness (1994) pointed out that earnings management practices raise the most important ethical issues facing the business profession.

\section{Earnings management in a code-law country: the Spanish case}

In 1990, Bruns and Merchant conducted a survey on the morality of short-term earnings management that was published in Harvard Business Review. The authors considered their results as being "frightening" based on the higher rate of acceptability of those practices. Despite their attempt to increase accountability by placing short-term earnings management under the aegis of immoral and unethical practices, little progress has been done

since that moment. Moreover, today some proponents still argue in favor of using those practices (Lin et al., 2012; Graham et al., 2005), despite the fact that this means misinterpretation, manipulation and deliberate deception for the users of accounting information.

It is well known that social norms and specific cultural practices seem to drive the assessment about ethicality and morality of people and their actions (Appiah, 2008; Knobe and Nichols, 2008). Based on this fact a culturally relativist view of ethics (Driver, 2007) is possible. According to Leuz et al. (2003) earnings management is a pervasive corporate phenomenon, more prominent in code-law countries than common-law countries. Also, studies documented that certain practices of earnings management (e.g. income smoothing or payout-driven income decreasing) are typical for code-law countries like Spain (Azofra et al., 2003; Leuz et al., 2003). 
Based on the view of Callao et al. (2007), Spain is a country where the legal system is based on Roman law and furthers the accounting rules are enshrined in legislation. Comprising a Continental European accounting system, the Spanish accounting rules have taken the form of companies' legislation, the General Chart of Accounts with its implementing regulations and also other Securities Market and Bank of Spain legislation. Also, looking for the differences found between Spain and other developed countries (e.g. USA); we have found among the most important ones the institutional discrepancies. Other important difference is relying on the stock market development. While in USA the stock market is highly developed, Spain comprises far less developed stock markets, with far less companies listed on the interconnected market. Banks are the major source of business finance in Spain (Ojah and Manrique, 2005) sustaining important incentives for opportunistic behavior of managers (DeFond and Jiambalvo, 1994).

Summarizing other differences, those can be found both in the legal and judicial enforcement (LaPorta et al., 1998), differences that confirm the central role of enforcement mechanisms over financial-reporting practices (Burgstahler et al., 2006). According to Pindado and de la Torre (2006), Spanish CEOs managing quoted firms face little control by shareholders. Their evidence suggests that managers face few restrictions to maintain their informative advantage over different creditors and shareholders.

La Porta et al. (1998) include Spain in the "French family" within the code-law tradition and argue for comparison with two other code-law "families" (e.g. Scandinavian and German), "French family" countries which gives shareholders and creditors the weakest protection. Confirming this trend,Hope (2003a) placed Spain in last position among 22 countries regarding enforcement and disclosure.

All above references sustain the evidence of high levels of manipulation in code-law countries but do not examine whether they are increasing or decreasing or what incentives are 
driving them. Building on this evidence, Garcia Lara (2006) offers arguments in order to find the incentives underling continental European managers to engage in earnings management activities more than their common-law counterparts (Leuz et al., 2003). Among them, the authors argue for: existing links between reported income and current payouts to different stakeholders; the pecking order theory and the less-pronounced market pressure to manage earnings upwards.

Comparing the incentives for engaging in earnings management practices found in code-law countries with those documented in common-law countries with highly developed financial markets, many differences can be found. Among them we can summarize the following: the reluctance of managers to make direct disclosures of private information to shareholders based on both institutional and legal constrains (Schipper, 1989); lack of credible channels for appropriate disclosures (Demski and Sappington, 1987); communicate proper knowledge regarding firm`s superior earnings prospects to investors (Alissa et al., 2013); differentiate from inferior prospects in the capital markets (Chaney and Lewis, 1995); obtaining a higher valuation for the shares (Barth et al., 1999; Baker et al., 2009); obtaining a lower cost of capital (Francis et al., 2004); meeting earnings thresholds (Degeorgeet al., 1999; Daniel et al., 2008); management-compensation plans (Healy, 1985; Holthausenet al., 1995), debt contracts (DeFond and Jiambalvo, 1994); avoiding decreases and losses (Burgstahler and Eames, 2003).

Various studies conducted so far in the literature comprised a large variety of accrual prediction models in order to assess for different objectives. Those models were used to detect earnings management, based on the accepted hypothesis that earnings are managed in predictable ways in response to certain incentives (Healy, 1985; Watts and Zimmerman, 1986; Schipper, 1989; Holthausen et al., 1995; Jones, 1991; Cahan, 1992). Examining even deeper how earnings are managed, the discretionary accruals are estimated using accrual 
prediction models. Unusual accruals are then compared with forecasts from an accrual prediction model and the forecasts errors are assumed to represent earnings management.

According to Stolowy and Breton (2004) the main research designs employed for assessing earnings management can be found comprised mainly in three categories as follows: research designs using discretionary accruals (e.g. Jones, 1991; Dechow et al., 1995); research designs using specific accruals (e.g., McNichols et al., 1988), and those that examine the statistical properties of earnings in order to identify thresholds (e.g. Degeorge et al., 1999).

Even if those research designs are still among the most used ones among the scholars worldwide, in recent years, much attention has been paid to both relative and absolute accuracy of those accrual models (Dechow et al., 1995; Guay et al., 1996; Thomas and Zhang 2000;Dechow et al., 2010 and DeFond (2010).

Mainly their ability to identify Type I and II errors was and still is under scrutiny (Dechow et al., 2012), since many of the models used for assessing accrual earnings management are found as having comprised important limitations. Among one of the most important limitations is the assuming used in time-series approach for temporal stationary of parameter estimates, whereas the cross-sectional approach assumes homogeneity across firms in the same industry (Larker and Richardson, 2004). Other limitation consists in the fact that almost all techniques used so far are based on the assumption that unexplained or abnormal accruals represent explicit earnings management. One can also argue that those abnormal accruals can be poor quality earnings. That is the main reason why current research designs used to detect earnings management suffers from: measurement errors and correlated omitted variables while most of them do not take into account the dynamic of earnings.

Taking into account the advantages of ratios analysis, we can assert that this demarche can comprise a simpler path for detecting earnings management. Other potential advantage 
consists in lacking one of the most important limitations found so far in the most used research designs.

Based on those arguments, previous research documented ratios analysis that was used so far in the context of earnings management in order to measure discontinuities in distributions (Glaum et al., 2004) or to discriminate manipulators from non-manipulators (Beneish, 1999; Jansen et al., 2012). The focus of our paper is on the latter approach based on the advantages attached in this paper (Beneish, 1999).

On the other hand, ratio analysis can be also susceptible to faulty interpretation and is potentially confusing (Altman, 1968). The challenge regarding ratio analysis is to combine several measures into a meaningful predictive model. The most important question is which ratios and what weights should be attached to those ratios used to discriminate manipulative behavior from non-manipulative. In order to fill this gap we conducted this empirical study.

\section{Research design}

As we stated earlier, our paper is an empirical exercise developed as having the goal to set the tolls to discriminate manipulators from non-manipulators companies for the case of the Spanish market. In this respect two relevant research questions spring as follows:

(1) Which accounting ratios can be used as influential ones in order to distinguish between manipulators versus non-manipulators companies?

(2) What should be their relative importance?

After careful consideration of the nature of the problem and of the purpose of the paper two different statistical methodologies were used: (i) Linear Discriminant Analysis (hereunder LDA) and (ii) Probit model. 
Both of the previous statistical methodologies are grounded in a multivariate approach as it is encouraged by Altman (1968) implying a natural extension for a univariate analysis. While Probit model deserves no additional explanations, LDA was chosen to be applied in our paper based on three arguments: this technique considers an entire profile of characteristics common to the relevant firms and also the interaction of these properties; this study is concerned with two groups only, LDA was considered properly in this respect since it permits the reduction of the space dimensionality and finally, LDA was chosen taking into account its potential in dealing with classification problems when analyzing the entire variable profile of the object simultaneously rather than sequentially by examining its individual characteristics.

Since financial ratios, by their nature, have the effect of deflating statistics by size, the size effect is eliminated. Based on the large numbers of variables found to be significant indicators in the arena of manipulative behavior in past studies (Beneish, 1999; Mulford and Comiskey, 2002; Schilit, 2010), a list of 12 explanatory variables (ratios) was compiled for evaluation. Similarly to Altman (1968), the 12 variables were chosen on the basis of their popularity in the literature and potential relevancy to our study. From the original list of variables, 3 variables were selected as doing the best overall job together in the prediction of earnings management. Also, similar like in Altman (1968), in order to arrive at the final profile of variables the following procedures are utilized:

1) Observation of the statistical significance of various alternative functions comprising the determination of the relative contributions of each independent variable;

2) Evaluation of inter-correlations between the relevant variables;

3) Observation of the predictive accuracy of the various profiles, and

4) Judgment of the analyst.

\subsection{Statistical methodology}


Since LDA and Probit Models are the appropriate techniques to classify observations between groups, the next subsections are devoted to make a brief description of their salient features. Additionally, Multivariate Analysis of Variance (hereunder MANOVA) is discussed in order to detect those independent variables with the highest discriminant power.

\subsubsection{MULTIVARIATE ANOVA (MANOVA)}

Assume a sample coming out from two possible different groups (manipulators and non-manipulators), where each observation has differentvariables (accounting ratios). The question is to which extent these groups are actually different regarding these variables. Under this setting, this technique is particularly useful in identifying the group of variables (accounting ratios) that shows a different performance between manipulators and nonmanipulators. In other words, the definition of the set of indicators with the highest discriminant power is backed on this methodology. Variables not presenting different profiles between groups are of little use to discriminate observations.

\subsubsection{Linear discriminant analysis (LDA): Two group case}

This technique attempts to derive a linear combination of variables (accounting ratios) that maximizes the separation between two groups. The discrimination is achieved by finding the vector that contains the discriminant weights for each of the independent variables that best separate individual observations coming out from different population (manipulators and non-manipulators).

In order to assess the discriminant accuracy of the model, two alternatives are proposed, both of them are back on the classification matrix. Since our study is a multi-group 
case, below classification chart presented in Table 1 is used, where the main diagonal accounts for the correct classification and out of it the classification errors.

Table 1. Classification chart

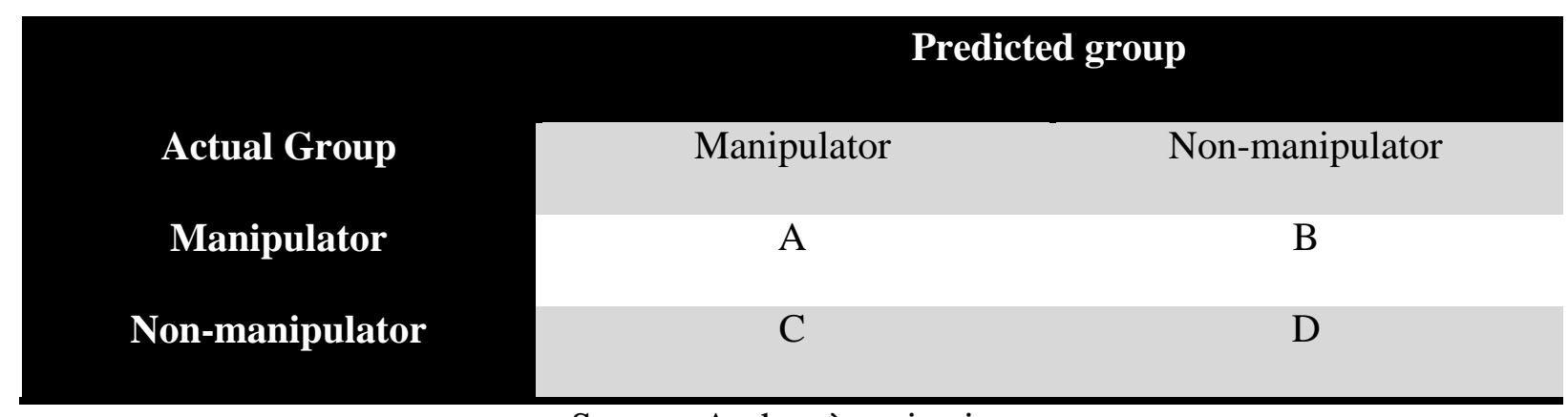

Source: Authors`projection

Similar to Beneish (1999), the actual membership is equivalent to the a priori grouping and the model attempts to classify correctly these companies. When new companies are classified, the nature of our model is predictive.

\subsubsection{PROBIT and LOGIT models}

Models for binary choice are a class of econometric models where the "dependent" variable is qualitative assuming only two values $(0 / 1)$. It is traditional to quantify with 1 a success and with 0 a failure. In the present case, manipulator's firms will be set equal to 1 and non-manipulator to 0 respectively. Among this econometric class, Probit and Logit represent the most prominent models.

\subsection{Accounting variables indicating earnings manipulation}


Since we cannot rely on any economic theory of manipulation, we comprised in our study explanatory accounting variables from positive accounting theory research (Watts and Zimmerman, 1986) and both cash flow and accruals (Healy, 1885; Jones, 1991; Dechow et al., 1995). Other variables were comprised based on the work of investigation in terms of accounting manipulation conducted by scholars like Mulford and Comiskey (2002) and Schilit (2010). The explanatory accounting variables were calculated based on accounting financial data found in the financial statements of the companies examined. Similar to Beneish (1999) some of the variables are designated as indices since they are intended to capture distortions that could arise from manipulation by comparing financial statement measures in the year of the first reporting violation to the year prior. We also took in consideration the findings of Feroz et al. (1991), who asserted that manipulation becomes public on average after 19 months after the end of the fiscal year of the first reporting violation.

In order to estimate the models from section 1, we used a list of firms identified as manipulators (12) (including the year of the manipulation) and non-manipulators (59). Additionally, accounting information for those firms was also provided in order to calculate a set of independent variables (12 in total) capturing different dimensions of earning's manipulation. Next, we summarized the list of independent variables with a brief explanation of their meaning and the expected sign in the regressions. It is worth mentioning that in the definition of the variables, period $\boldsymbol{t}$ corresponds to the year of manipulation.

1-Receivables Index $(R I)$ : RI is the ratio of accounts receivables in sales in the first year in which earnings manipulation is uncovered (year t) to the corresponding measure in year $\mathrm{t}-1$. 
This variablewas included based on the fact that it gauges whether receivables and revenues are in or out-of-balance in two consecutive years. A large increase in the amount of receivables can be the result of a change in credit policy used in order to increase sales as a result of increased competition or revenue inflation. It is expected a positiveassociation with the probability of manipulation as long as receivables assumes a disproportional large value relative to Sales for the year of manipulation.

2-Inventories Index (II): II is the ratio of inventories in cost of goods sold in year t to the corresponding measure in previous year. A disproportionally increase in inventories could indicate possible manipulation by artificially changing its value. A positiveassociation is expected.

3- Gross Margin Index (GMI): GMI is the ration of gross margin in year t-1 to gross margin in year t. When its value is higher than 1 , it indicates that gross margins have deteriorated, interpreted as a negative signal about firms` prospects (Lev and Thiagarajan, 1993).Since companies with poor prospects are more likely to engage in earnings manipulation, a positive sign it is expected (Kellogg and Kellogg, 1991). Deterioration in Gross Margins makes engaging in earning manipulation a more likely event.

4-Sales Growth (SG): SG is the ratio of sales in year $\mathrm{t}$ to sales in previous year (t-1). Growth per se does not have to be regarded as a manipulative event, but according to professional bodies like the National Association of Certified Fraud Examiners (1993), growth companies must be treated with caution. The explanation relies in the behavior of such companies, as being more expected to commit fraud since the need of achieving earnings targets is higher comparing to other types of companies. Since the perception of losing stock prices or decelerating growth can be costly (Loebbeckke et al., 1989; Fridson, 1993), those companies can deal with important incentives to manipulate earnings. It is expected a 
positiverelationship based on the fact that a reduction in sales would encourage management to engage in manipulation.

5-Depreciation Index (DI): DI is the ratio rate of depreciation in year t-1 to the corresponding measure in year $\mathrm{t}$. A significant change in the depreciation change is associated with a change in the estimates of assets lives or adopted a new method of depreciation. Those firms reducing the rate of depreciations are suspect of manipulation by artificially increasing the useful lives of company's assets. Then, it is expected a positiverelationship between DI and the probability of manipulation. This variable did not enhance neither the specification of our model nor it alters the magnitude of the significance of the coefficients of the other explanatory variables used.

6-Discretionary Expenses Index (DEI): DEI is the ratio of discretionary expenses in year $\mathrm{t}$ to discretionary expenses in $\mathrm{t}-1$. Reducing discretionary expenses in the year of manipulation is an indication of manipulation by artificially improving the firm's prospect (Lev and Thiagarajan, 1993). A positiveassociation is expected between DEI and the probability of manipulation.

7-Leverage Index 1 (LI1): LI1 is the ratio of current debt to total assets in year $\mathrm{t}$ relative to the corresponding measure in previous year. If the value of this ratio is higher than 1 is obtained an increase in the leverage index. High leverage could encourage accounting manipulation through its effect on debt covenants with the firm's (current and future) counterparties (Beneish and Press, 1993). A positivesign in the regression is expected between LI1 and the probability of manipulation.

8-Leverage Index 2 (LI2): idem to LI1 but standardized by Sales. A positiveassociation is expected, between LI2 and the probability of manipulation.

9-Asset Quality (AQ): AQ is the ratio of asset quality in year t relative to asset quality in previous year, measuring the proportion of total assets for which future benefits are 
potentially less certain (e.g. assets realization risk analysis suggested by Siegel, 1991). If its value is higher than 1 it indicates that the firm has potentially increased its involvement in cost deferral (Beneish, 1999). Since is possible that part of the increase is attributable to acquisitions involving Goodwill, we assessed the sample manipulators in terms of acquisitions. Since this is not the case for our manipulators sample, we predict a positive relationship between asset quality and earnings manipulation.

10-CFO Index 1 (CFO1): A fall in CFO relative to Net Income indicates an increase in the proportion of accrual relative to Net Income. This provides more room to manipulate. Then, a positive association is expected, between CFO1 and earnings manipulation.

11-CFO Index 2 (CFO2): Idem to CFO1 but standardized by Total Assets. Similar to CFO1 a positive sign is expected between $\mathrm{CFO} 2$ and earnings manipulation.

12-Sales Index (SI): $\mathrm{SI}$ is the ratio of sales in year $\mathrm{t}$ to $\mathrm{CFO}$ in year $\mathrm{t}$, relative to the same measure in previous year (t-1).A disproportionate increase in Sales not mapped into CFO could indicate an artificial inflation (Mulford and Comiskey, 2002). Therefore, a positive sign of this variable is predicted, case in which a manipulation case is indicated.

\section{Data set construction}

The final data set consists of 12 manipulators and 59 non-manipulators matched by industry and year of manipulation (71 data points). The financial industry was discarded because of its specific characteristics which are endowed with the industry`s own accounting and financial rules.

All companies examined in our study are listed on the Spanish Stock Exchange, tier 1, and period 2005-2012. These data were obtained from CNMV, the Spanish stock exchange supervisor. 
There is one firm identified as belonging to the first group that is outside of the sample because it does not present information in the previous year of the event. Additionally, there are two firms no considered in the control group in particular years based on the lack of financial information. It is worth mentioning that since information regarding to CFO starts from 2007, 9 observations of the data set were discarded when variables including CFO in their calculation were considered. In this case, the data set has 62 data points (10 manipulators and 52 non manipulators).

Finally, since several of the independent variables are indices with small denominator, we winsorized the data set at $5 \%$ and $95 \%$ percentiles for each variable. Additionally, some of the balance sheet items assume value zero in different years affecting the calculation of the independent variables when they appear in the denominator. In this case, we put 1 as it is suggested by Beneish (1999).

\section{Estimations results}

As it was mentioned previously, since information regarding $\mathrm{CFO}$ is available from 2007, it implies a considerable reduction in the sample size from 71 to 62 observations (13\%) which undermines the robustness of the estimations. Nevertheless, our results do not suffer any changes when CFO variables are included. Therefore, in what follows we will just discuss the results considering the larger data set (the results from the smaller data are available on request).

As we explain in the Appendices, among all possible combination of variables MANOVA is used to select those arrangements showing the greatest discriminatory power. This is a fundamental step in determining which ones were the crucial accounting ratios that significantly differentiate a manipulator firm from a non manipulator one. We can assert that 
not every accounting ratio can act like a fundamental variable used in order to identify companies that do manipulate their earnings.

According to the results presented in Table 2 in the Appendices, it seems that the critical explanatory variables identifying a manipulator are:

(1) Receivables index: when it increases

(2) Leverage index 1 (e.g. current debt/total assets): when it increases

(3) Sales Growth: when it decreases

All those explanatory variables show the expected sign (e.g. positively associated).

Table 3in the Appendicespresents the major statistic regarding Z-scores for the six models including the region of ignorance (Altman, 1968). In this respect, our models correctly classify a non-manipulator firm when its Z-score is lower than the minimum of the "region of ignorance" and correctly classify as manipulator when its z-score is above the maximum of the same region.

Accordingly, the explanatory accounting ratios found to be significant in terms of manipulation indication based on the discriminate analysis conducted (e.g. Receivables Index, Sales Growth, Leverage Index 1) are shown to be fundamental ratios in indication manipulation also according to Probit estimations.

\section{Conclusion, limitation and scope for future research}

Since companies have a social responsibility also ethics should be part of the corporate strategy, conducting to optimizing its profits in a sustainable way. Given the economic and social consequences of their actions, companies depend on the moral integrity of their managers. In this respect, core values like truthfulness and honesty in act and spirit should be respected per se and not only to avoid penal action. In the light of previous scandals in the 
business arena, there is a stringent need for moral behavior and people of moral integrity who are willing to act in accordance with accepted moral standards. Most of all, one should be aware of the fact that if we fail to translate ethical behaviors into organizational practices, we risk not only moral shortcuts but also we will be unable to prevent and limit future economic crisis, followed of what is most important - confidence crisis.

Both individual practitioners, their organizations and also professional associations and accounting regulators should take steps to identify and deter earnings management practices, by developing specific tools to assess its existence and magnitude. Regarded from an ethical perspective as morally reprehensible, accounts manipulation is not fair to users, it involves an unjust exercise of power, and tend to weaken the authority of the regulators and supervisors. Being part of a continuous debate that seems to rest ultimately on heterogeneous personal preferences of the producers of accounting information, accounts manipulation acceptance often vary in terms of ethicality.

Today`s business environment it seems to be interested on what rules people should follow and why they are following those particular rules rather than what kind of person should one become, complying in this respect with a central post-Nietzschean view as MacIntyre (1981, p. 112) noticed. Further, this behavior can be explained by the failure of reason-based morality, which has left the modern world in a damaged state characterized by continuous debates over rules and continuous camouflage of ethical behavior. In this respect, a Kantian approach (Kant, 1994) regarding the organization can be a possible solution.Committed to achieve common goals and moral communities, a Kantian approach to business environment will regard the organization other than merely a means of achieving individual goals.

Regarded most often as a reprehensible behavior, accounts manipulation examination raised in recent years a continuous interest on behalf of academia, regulators and media. Part of this trend, this paper has developed a model for detecting earning manipulators using 
financial statements ratios. Our empirical study extends the literature of ratio analysis combined with rigorous statistical technique used in the context of manipulative behavior by presenting a methodology used to distinguish manipulators from non-manipulators companies. The empirical evidence in our paper is based on a sample of companies whose manipulation of earnings was discovered and a sample of companies known as following the "good practices" in accounting in the period 2005-2012.

The study conducted is similar to the study conducted by Beneish (1999), in this respect we used financial data in order to construct the variables that seek to capture the effects of manipulation and predispositions that may prompt companies to engage in earnings management practices.

Our study confirms the predictive content of the explanatory variables (e.g. accounting ratios) that take into account the simultaneous bloating in asset accounts.

The results of our paper document that receivables and leverage have discriminatory power since the primary characteristic of sample manipulators is that they have higher growth prior to periods during which manipulation is in force. We have found also that the sample of manipulators overstate earnings comparing to the sample of non-manipulators. The context of earnings manipulation is the annual report. Our evidence document that the probability of manipulation increase with the following: (1) unusual increase in receivables; (2) increasing leverage and (3) decrease in sales.

By other hand we haveobtained several $\mathrm{Z}$ scores that can be used to assess the probability that a company manipulates its accounts.

We consider of interest the systematic association between earnings manipulation and financial statement data, for both accounting scholars and professionals. In the light of previous financial scandals, accounting information should not only meet the test of providing 
useful information but also should enable an assessment of reliability how Beneish (1999) suggested.

Our proposed methodology can help on the above assessment. Being simpler than other tools used in order to detect earnings management practices, our methodology only requires two years of data to evaluate the likelihood of manipulation. Our methodology, similar to the methodology used by Beneish (1999), can be inexpensively applied by the Spanish stock exchange regulator or similar regulators in other countries, but also by professional investors or auditors.

Being primarily cost-effective, our methodology that explores the distortions in financial statement data that could result from manipulation can be used on a large scale by all categories above and many other users of accounting information.

The research conducted has several important limitations. A first limit consists in the fact that we recognized the explored distortions as a result from manipulation, when one can argue that such distortions in financial ratios can have alternative origins (for instance they could be the result of a significant change in the firm`s economic environment). A second limitation consists in the potential bias that has the potential to interfere in the case of both sampling errors in the original sample (based on the fact that part of the sample was constructed manually) and search bias. Similar to Altman (1968), this bias is inherent in the process of reducing original set of variables to the best variable profile. Also, we share a similar view with Altman (1968) and assert that while a subset of variables is effective in the initial sample, there is no guarantee that it will be effective for the population in general. The results are also insensitive to the choice of estimation and holdout samples.

To summarize the above, our results need to be interpreted in the light of possible sample selection bias. The estimation is based on a sample of discovered manipulators. Similarly to Beneish (1999), it is possible that there are successful, unidentified manipulators, 
and the results need to be interpreted assuming that sample manipulators represents a substantial portion of the manipulators in the population. Given this shortcoming, our evidence documenting a systematic relation between the likelihood of manipulation and financial statement variables argue for the usefulness of accounting data in detecting manipulation and further assessing the quality of accounting earnings.

Future research can extend our methodology to privately-held companies, not only listed ones as it is the case of our study. Also, future research can try to enlarge the sample, using listed or privately-held companies from many other code-law countries. Another potential spring of future research is to build a reliably model that can be used to examine companies that are conducive to decreasing earnings and not only companies that overstatement earnings. Further contribution to the earnings management ethics literature can be addressed by focusing on ethical judgments and intentions to intervene when the consequences of such behavior are positive for the companies. In this respect it will be interesting to assess the self-deception that managers sometimes undertake to justify morally questionable actions for the greater good of the company when the cost of telling the truth is too high. 


\section{APPENDICES}

\section{ANALYSIS OF THE DATA}

\section{a) MANOVA and LDA}

Among all possible combination of variables (there are 512 possible models); MANOVA is used to select those arrangements showing the greatest discriminatory power. ${ }^{1}$ This is a fundamental step in determining which ones were the crucial accounting ratios that significantly differentiate a manipulator firm from a non manipulator one. Table 2 reports the p-values of MANOVA and the discriminator coefficient for the complete model (a model including all the accounting variables) and for five models showing the smallest p-value from MANOVA test.

Table 2. P-values of MANOVA and discriminator coefficient for the models tested

\footnotetext{
${ }^{1}$ Since there are 9 independent variables, the total number of possible models is $29=512$
} 


\begin{tabular}{|c|c|c|c|c|c|c|c|c|c|c|c|c|}
\hline & $\begin{array}{l}\text { ANOVA } \\
\text { p-vahre }\end{array}$ & $\begin{array}{c}\text { Receivables } \\
\text { Index }\end{array}$ & $\begin{array}{l}\text { Inventories } \\
\text { Index }\end{array}$ & $\begin{array}{l}\text { Gross } \\
\text { Margin } \\
\text { Index }\end{array}$ & $\begin{array}{l}\text { Sales } \\
\text { Growth }\end{array}$ & Dep. Index & $\begin{array}{l}\text { Discret. } \\
\text { Expenses } \\
\text { Index }\end{array}$ & $\begin{array}{l}\text { Leverage } \\
\text { Indes } 1\end{array}$ & $\begin{array}{l}\text { Leverage } \\
\text { Index } 2\end{array}$ & $\begin{array}{l}\text { Asset } \\
\text { Quality }\end{array}$ & $\mathrm{H}$ & $\begin{array}{c}Q \\
\text { p-vahie }\end{array}$ \\
\hline & & $\mathrm{RI}$ & II & GMI & SG & DI & DEI & LI1 & LI2 & $\mathrm{AQ}$ & & \\
\hline \multicolumn{13}{|l|}{ Model 1} \\
\hline Coefficient & 0.27 & 0.34 & -0.66 & -2.31 & 2.55 & -0.72 & 0.41 & 2.40 & -0.95 & 0.86 & 0.75 & 0.00 \\
\hline \multicolumn{13}{|l|}{ Model 2} \\
\hline Coefficient & 0.04 & & & & 1.19 & & & & & & 0.77 & 0.00 \\
\hline \multicolumn{13}{|l|}{ Model 3} \\
\hline Coefficient & 0.06 & 0.28 & & & 1.05 & & & & & & 0.75 & 0.00 \\
\hline \multicolumn{13}{|l|}{ Model 4} \\
\hline Coefficient & 0.06 & 0.34 & & & 2.25 & & & 2.13 & -0.85 & & 0.75 & 0.00 \\
\hline \multicolumn{13}{|l|}{ Model 5} \\
\hline Coefficient & 0.07 & & & & 2.10 & & & 2.15 & -0.67 & & 0.73 & 0.00 \\
\hline \multicolumn{13}{|l|}{ Model 6} \\
\hline Coefficient & 0.08 & & & & 1.07 & & & 0.86 & & & 0.72 & 0.00 \\
\hline
\end{tabular}

Based on the values presented in Table 2 some important conclusions can be drawn. Staring with our complete model (including RI, II, GMI, SG, DI, DEI, LI1, LI2, AQ) we can assert that the p-value of MANOVA test (e.g. 0.27) is not significant. Based on this latter conclusion, we can assert that not every accounting ratio can act like a fundamental variable used in order to identify companies that do manipulate their earnings. Assessing the second model (presented in Table 2), the p-value of MANOVA test (e.g. 0.04) shows that this model is significant in predicting a differential profile between manipulators and non-manipulators. In this respect the SG ratio can be used to discriminate between manipulators and nonmanipulators. The third model is also found to be significant (p-value of MANOVA test: 0.06). Therefore, RI and SG ratios are found significant in discriminating manipulators from non-manipulators. Models five and six introduces as significant discriminator the LI1 (p-value of MANOVA test in model 5: 0.06 and p-value of MANOVA test in model 6: 0.07).

According to the results presented in Table 2, it seems that the critical explanatory variables identifying a manipulator are: (1) Receivables index; (2) Sales Growth and (3) Leverage index 1 (e.g. current debt/total assets). All those explanatory variables show the 
expected sign (e.g. positively associated). Their statistically significance is assessed in section 5.2.

LI2 (e.g. leverage index 2: current debt to sales) deserves a special comment since it seems to act like a discriminator variable according to the results presented in Table 2, but its sign is opposite to the expected one (negatively associated).

The Hit ratio $(\mathrm{H})$ assumes values between $72 \%$ and $77 \%$, showing that the models are doing a good job in matching the actual group of companies with the one expected from the zscores. The lowest value of Hit ratio we obtained is for model six (including accounting ratios like SG and LI1), while the highest values is obtained for model two (including SG as accounting ratio). Finally, the $\mathrm{Q}$ test shows strong evidence in favor of our models. The assignment of firm to a particular group is by no means made randomly, consistent with previous argument.

Table 3 presents the major statistic regarding z-scores for the six models including the region of ignorance (Altman, 1968). In this respect, our models correctly classify a nonmanipulator firm when its z-score is lower than the minimum of the "region of ignorance" and correctly classify as manipulator when its z-score is above the maximum of the same region.

When Z-scores belong to the region of ignorance, the discriminant power of the models is undermined. The "region of ignorance" is that range of Z-scores where misclassifications are observed. Hence, it is desirable to establish a guideline for classifying firms in the "region of ignorance".

Table 3. Z-scores: Key parameters 


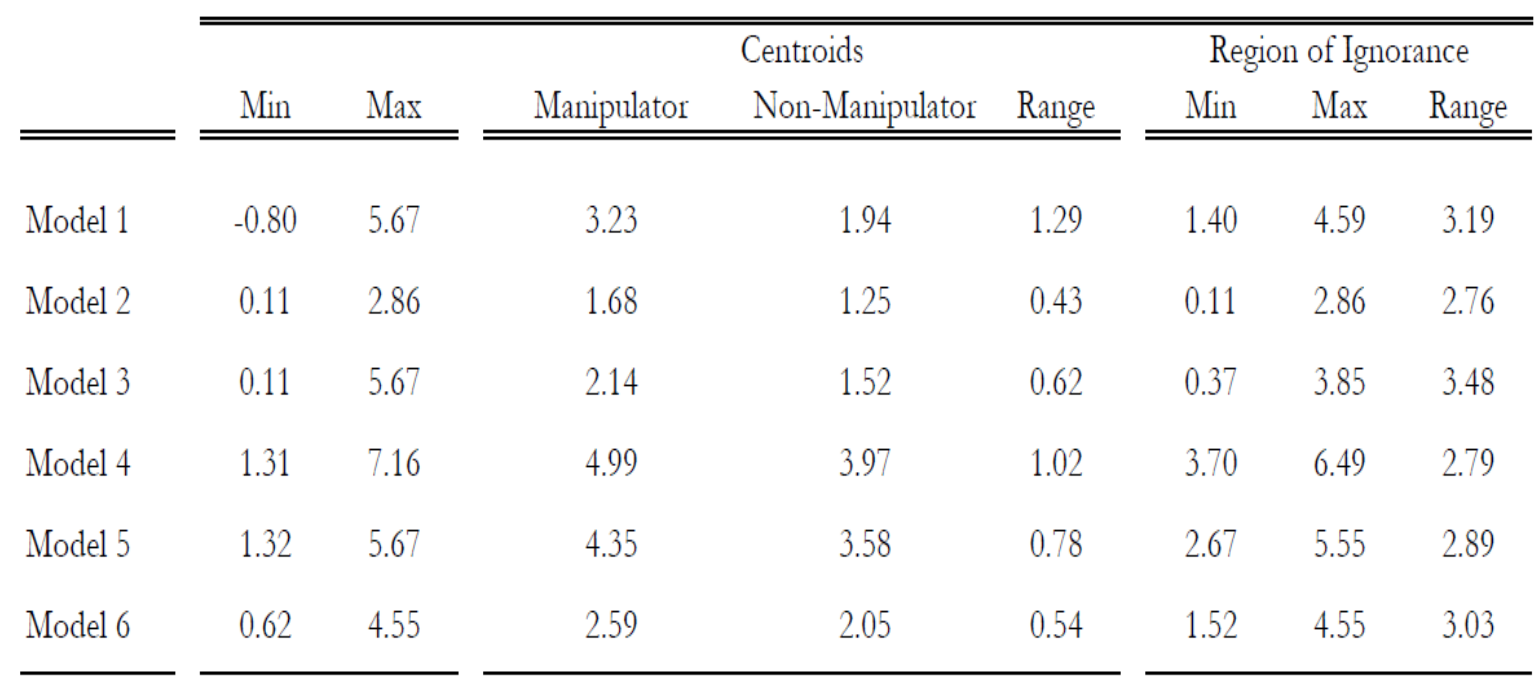

According to the results presented in Table 3, the complete model obtained a minimum value for the $\mathrm{Z}$-score of -0.80 while the maximum value is 5,67 . The range value for the centroids is 1.29. The minimum of the "region of ignorance" is 1.40 while the maximum is 4.59 , with a range of 3.19. Model two and Model three has a similar value for the minimum of Z-score (e.g. 0.11) while the maximum values are higher in case of Model 3 (e.g. 2.86 - Model 2; 5.67 - Model 3). For Model two the values obtained for the minimum and maximum of the "region of ignorance" are similar to the minimum and maximum of the values obtained for its Z-score. For Model four, we obtained the highest value of the Z-score (7.16) comparing to the other models and the highest maximum for the "region of ignorance" (6.49). The centroids value for manipulators is 4.35 for Model five and 3.58 for nonmanipulators. For the last model tested the value of the centroids for manipulators is only 2.59 and for non-manipulators 2.05 , with a range of only 0.54 , second as low value obtained, after the Model two. Summarizing, the lowest value obtained for the minimum of the "region of ignorance" is obtained for the second model $(0.11)$ while the highest maximum value is obtained as we asserted earlier for Model four (6.49).

\section{b) PROBIT MODEL}


As a robustness check, the results of The Probit estimations for each of the six models are reported in Table 4. In this respect each of the six models are assessed in terms of descriptive validity.

Table 4. Results of Probit estimations

\begin{tabular}{|c|c|c|c|c|c|c|c|c|c|c|c|c|}
\hline & \multicolumn{12}{|c|}{ PROBIT MODEL } \\
\hline & Const & $\begin{array}{c}\text { Receivables } \\
\text { Index } \\
\text { RI }\end{array}$ & $\begin{array}{c}\text { Inventories } \\
\text { Index } \\
\text { II }\end{array}$ & $\begin{array}{c}\text { Gross } \\
\text { Margin } \\
\text { Index } \\
\text { GMI } \\
\end{array}$ & $\begin{array}{c}\text { Sales } \\
\text { Growth } \\
\text { SG }\end{array}$ & $\begin{array}{c}\text { Dep. Index } \\
\text { DI } \\
\end{array}$ & $\begin{array}{c}\text { Discret. } \\
\text { Expenses } \\
\text { Index } \\
\text { DEI }\end{array}$ & $\begin{array}{c}\text { Leverage } \\
\text { Index } 1 \\
\text { LI1 }\end{array}$ & $\begin{array}{c}\text { Leverage } \\
\text { Index } 2 \\
\text { LI2 }\end{array}$ & $\begin{array}{c}\text { Asset } \\
\text { Quality } \\
\text { AQ } \\
\end{array}$ & $\begin{array}{c}\text { Pseudo } \\
\mathrm{R}^{\wedge} 2\end{array}$ & $\begin{array}{l}\mathrm{Chi}^{\wedge} 2 \\
\text { p-vahre }\end{array}$ \\
\hline Predicted Sign & & $(+)$ & $(+)$ & $(+)$ & $(+)$ & $(+)$ & $(+)$ & $(+)$ & $(+)$ & $(+)$ & & \\
\hline \multicolumn{13}{|l|}{ Model 1} \\
\hline $\mathrm{p}$-vahues & 0.85 & 0.13 & 0.35 & 0.56 & 0.01 & 0.25 & 0.94 & 0.06 & 0.06 & 0.55 & & \\
\hline \multicolumn{13}{|l|}{ Model 2} \\
\hline Coefficient & -1.67 & - & - & - & 0.60 & - & - & - & - & - & 0.06 & 0.05 \\
\hline $\mathrm{p}$-vahres & 0.00 & - & - & - & 0.05 & - & - & - & - & - & & \\
\hline \multicolumn{13}{|l|}{ Model 3} \\
\hline \multicolumn{13}{|l|}{ Model 4} \\
\hline Coefficient & -3.54 & 0.18 & - & - & 1.29 & - & - & 1.32 & -0.51 & - & 0.15 & 0.05 \\
\hline $\mathrm{p}$-vahues & 0.00 & 0.12 & - & - & 0.02 & - & - & 0.06 & 0.08 & - & & \\
\hline \multicolumn{13}{|l|}{ Model 5} \\
\hline Coefficient & -3.13 & - & - & - & 1.16 & - & - & 1.21 & -0.38 & - & 0.11 & 0.06 \\
\hline $\mathrm{p}$-vahres & 0.00 & - & - & - & 0.03 & - & - & 0.08 & 0.15 & - & & \\
\hline \multicolumn{13}{|l|}{ Model 6} \\
\hline Coefficient & -2.13 & - & - & - & 0.55 & - & - & 0.44 & - & - & 0.08 & 0.09 \\
\hline p-vahres & 0.00 & - & - & - & 0.08 & - & - & 0.28 & - & - & & \\
\hline
\end{tabular}

Consistently with the results from the discriminate analysis conducted, the models two to six present descriptive validity (with p-values of between 0.05 and 0.09 ). In this respect, Model two and four has a p-value of of 0.05 , while Model five obtained 0.06. The p-values for for Model six is 0.09 . The p-value of for our complete model (Model 1) is 0.19 which is consistently with previous results obtained. Further, in most of the cases, the estimated coefficients present signs according to theory (e.g. positively associated) and they are statistically significant, according to the values obtained and presented in Table 4. Accordingly, the explanatory accounting ratios found to be significant in terms of manipulation indication based on the discriminate analysis conducted (e.g. Receivables Index, Sales Growth, Leverage Index 1) are shown to be fundamental ratios in indication manipulation also according to Probit estimations. Finally, as it was mentioned previously 
Leverage Index 2 shows a negative and significant coefficient, an unexpected phenomenon since it is opposite to theory. 


\section{References}

Alissa, W., Bonsall IV, S.B., Koharki, K. and Penn Jr., M.W. (2013). Firms' use of accounting discretion to influence their credit ratings. Journal of Accounting and Economics $55,129-147$.

Altman, E. I.(1968). Financial ratios, discriminant analysis and the prediction of corporate bankruptcy. The Journal of Finance 23(4), 589-609.

Apellaniz, P. and Labrador, M. (1995). El impacto de la regulacion contable en la manipulacion del beneficio. Estudio empırico de los efectos del PGC de 1990. Revista Espanola de Financiacion y Contabilidad 24(82), 13-40.

Appiah, K. A. (2008). Experiments in Ethics. Harvard University Press, Cambridge, MA.

Azofra, V., Castrillo, L.and Delgado, M.M. (2003). Ownership concentration, debt financing and the investment opportunity set as determinants of accounting discretion: Empirical evidence from Spain. Spanish Journal of Finance and Accounting 115, 215-255.

Badertscher, B. (2011). Overvaluation and the Choice of Alternative Earnings Management Mechanisms. The Accounting Review 86(5), 1491-1518.

Baker, T.A., Collins, D. L. and Reitenga, A.R. (2009). Incentives and Opportunities to Manage Earnings around Option Grants. Contemporary Accounting Research 26(3),649-672.

Ball, R. (2009). Market and political regulatory perspectives on the recent accounting scandals. Journal of Accounting Research 47, 277-323.

Barth, M.E., Elliott, J. A. and Finn, M.W. (1999). Market rewards associated with patterns of increasing earnings. Journal of Accounting Research 37(2), 387-413.

Beaudoin, C., Cianci, A. and Tsakumis, G. (2014). The Impact of CFOs' Incentives and Earnings Management Ethics on Their Financial Reporting Decisions: The Mediating Role of Moral Disengagement. Journal of Business Ethics, published on-line: March 2014. 
Beneish, M. D. and Press, E. (1993). Costs of Technical Violation of Accounting-Based Debt Covenants. The Accounting Review 68(2), 233-257.

Beneish, M.D. (1999). The detection of earnings manipulation. Financial Analysts Journal, 24-36.

Bruns, W. J. and Merchant, K.A. (1990). The Dangerous Morality of Managing Earnings. Management Accounting 72(2),22-25.

Burgstahler, D. and Eames, M. (2003). Earnings management to avoid losses and earnings decreases: Are analysts fooled?Contemporary Accounting Research 20, 253-276.

Burgstahler, D., Hail, L. and Leuz, C. (2006). The importance of reporting incentives: earnings management in European private and public firms. The Accounting Review 81(5), 983-1016.

Cahan, S. (1992). The effect of anti-trust investigation on discretionary accruals: A refined test of the political cost hypothesis. The Accounting Review 67, 77-95.

Callao, S., Jarne, J.I. and Lainez, J.A. (2007). Adoption of IFRS in Spain: Effect on the comparability and relevance of financial reporting. Journal of International Accounting, Auditing and Taxation 16, 148-178.

Chaney, P.K. and Lewis, C.M. (1995). Earnings management and firm valuation under asymmetric information. Journal of Corporate Finance 1(1), 319-345.

Choi, T.H.and Jinhan, P. (2011). Business ethics and financial reporting quality: Evidence from Korea. Journal of Business Ethics 103(3), 403-427.

Chung, R., Firth, M. and Kim, J. B. (2005). Earnings management, surplus free cash flow and external monitoring. Journal of Business Research 58, 766-776.

Daniel, N.D., Denis, D. J. and Naveen, L. (2008). Do firms manage earnings to meet dividend thresholds?Journal of Accounting and Economics 45, 2-26. 
Das, S., Shroff, P. and Zhang, H. (2009). Quarterly earnings patterns and earnings management. Contemporary Accounting Research26(3), 797-831.

Dechow, P. M., Sloan, R. G. and Sweeny, A.P. (1995). Detecting earnings management. The Accounting Review 70, 193-225.

Dechow, P. M. and Skinner, D. J. (2000). Earnings management: Reconciling the views of accounting academics, practitioners, and regulators. Accounting Horizons 14, 235-250.

Dechow, P., Hutton, A., Kim, J.H. and Sloan, R.G. (2012). Detecting Earnings Management: A New Approach. Journal of Accounting Research 50(2), 275-334.

Dechow, P., Sloan, R.G. and Sweeney, A.P. (1996). Causes and consequences of earnings manipulation: An analysis of firms subject to enforcement actions by SEC. Contemporary Accounting Research 13(1), 1-36.

Dechow, P.M., Ge, W. and Schrand, K. M. (2010). Understanding Earnings Quality: A Review of the Proxies, Their Determinants and Their Consequences. Journal of Accounting and Economics 50, 344-401.

DeFond, M. L. (2010). Earnings quality research: Advances, challenges and future research. Journal of Accounting and Economics 50, 402-409.

DeFond, M. L. and Jiambalvo, J. (1994). Debt covenant violation and manipulation of accruals. Journal of Accounting and Economics 17, 145-176.

Degeorge, F., Patel, J. and Zeckhauser, R. (1999). Earnings management to exceed thresholds. Journal of Business 72, 1-33.

Demski, J. S. and Sappington, D.E.M. (1987). Delegated expertise. Journal of Accounting Research 25(1), 68-89.

Dobson, J. (1999). Is shareholder wealth maximization immoral? Financial Analysts Journal $55,69-75$. 
Donaldson, T. and Preston, L. E. (1995). The stakeholder theory of the corporation: Concepts, evidence and implications. Academy of Management Review20, 65-91.

Driver, J. (2007). Ethics: The Fundamentals. Blackwell Publishing Ltd., Malden, MA.

Dye, R. A. (1988). Earnings Management in an Overlapping Generations Model. Journal of Accounting Research 26, 195-235.

Fama, E. (1980). Agency problems and the theory of the firm. Journal of Political Economy 88(2), 288-307.

Elias, R. (2002). Determinants of earnings management ethics among accountants. Journal of Business Ethics 40(1), 33-45.

Fama, E. and Jensen, M. (1983). Separation of ownership and control. Journal of Law and Economics 26, 301-325.

Feng, M., Ge, W., Luo, S. and Shevlin, T. (2011). Why do CFOs become involved in material accounting manipulations? Journal of Accounting and Economics 51, 21-36.

Feroz, E. H., Park, K. and Pastena, V.S. (1991). The Financial and Market Effects of the SEC's Accounting and Auditing Enforcement Releases. Journal of Accounting Research 29 (Supplement), 107-148.

Francis, J., LaFond, R., Olsson, P. and Schipper, K. (2004). Costs of equity and earnings attributes. The Accounting Review 79(4), 967-1010.

Fridson, M.S. (1993). Financial Statement Analysis: A Practitioner's Guide.John Wiley,New York.

Glaum, M., Lichtblau, K. and Lindemann, J. (2004). The extent of earnings management in the U.S. and Germany. Journal of International Accounting Research 3, 45-77.

Gong, G., Louis, H. and Sun, A.X. (2008). Earnings management, lawsuits, and stock-forstock acquirers' market performance. Journal of Accounting and Economics 46, 62-77. 
Graham, J. R., Harvey, C. R. and Rajgopal, S. (2005). The economic implications of corporate financial reporting. Journal of Accounting and Economics40, 3-73.

Grant, C., Depree, M. and Grant, G. (2000). Earnings Management and the Abuse of Materiality. Journal of Accountancy190, 41-44.

Greenfield, A. C., Norman, C. S., and Wier, B. (2008). The effect of ethical orientation and professional commitment on earnings management behavior. Journal of Business Ethics 83, $419-434$.

Guay, W.R., Kothari, S. P. and Watts, R. (1996). A market-based evaluation of discretionary accrual models. Journal of Accounting Research 34(Suppl. 3), 83-105.

Gunny, K.A. (2010). The Relation between Earnings Management Using Real Activities Manipulation and Future Performance: Evidence from Meeting Earnings Benchmarks. Contemporary Accounting Research, 27(3), 855-888.

Ewert, R. and Wagenhofer, A. (2005). Economic effects of tightening accounting standards to restrict earnings management. The Accounting Review 80(4), 1101-1124.

He, L. and Yang, R. (2014). Does Industry Regulation Matter? New Evidence on Audit Committees and Earnings Management. Journal of Business Ethics, published online: 14 January 2014.

Healy, P.M. (1985). The effect of bonus schemes on accounting decisions. Journal of Accounting and Economics 7, 85-107.

Holthausen, R., Larker, D. and Sloan, R. (1995). Annual bonus schemes and the manipulation of earnings. Journal of Accounting and Economics 19, 29-74.

Hope, O-K. (2003). Disclosures practices, enforcement and accounting standards and analysts' forecast accuracy: An international study. Journal of Accounting Research 41(2), $235-272$. 
Horton, J., Serafeim, G. and Serafeim, I. (2013). Does Mandatory IFRS Adoption Improve the Information Environment?Contemporary Accounting Research 30(1), 388-423.

Hsiang-Lin, C., Chung-Hua S. and Feng-Ching, K. (2008). Corporate social responsibility, investor protection, and earnings management: Some international evidence. Journal of Business Ethics 79(1-2), 179-198.

Huang, T., Szczesny, A. and Lenk, A.A. (2008). Substitution, availability and preferences in earnings management: Empirical evidence from China. Review of Managerial Science 2, $129-160$.

Huang, P., Louwers, T.J., Moffitt, J. S. and Zhang, Y. (2008). Ethical management, corporate governance, and abnormal accruals. Journal of Business Ethics83(3), pp. 469-487.

Jansen, I. P., Ramnath, S. and Yohn, T.L. (2012). A Diagnostic for Earnings Management Using Changes in Asset Turnover and Profit Margin. Contemporary Accounting Research 29(1), 221-251.

Jensen, M. and Meckling, W. (1976). Theory of the firm: managerial behavior, agency costs, and ownership structure. Journal of Financial Economics 3(4), 305-360.

Johnson, E., Fleishman, G., Valentine, S. and Walker, K. (2012). Managers' ethical evaluations of earnings management and its consequences. Contemporary Accounting Research29(3), 910-927.

Jones, J.J. (1991). Earnings management during import relief investigations. Journal of Accounting Research 29, 193-228.

Kant, I. (1994). The metaphysics of moral; The metaphysical principles of virtue (1797). In I. Kant, Ethical Philosophy2nd edn, Trans. by James W. Ellington. Hackett Publishing Company, Indianapolis/Cambridge, MA.

Kaplan, S. (2001). Ethically related judgments by observers of earnings management. Journal of Business Ethics 32(4), 285-298. 
Kellogg, I. and Kellogg, L.B. (1991). Fraud, Window Dressing, and Negligence in Financial Statements.McGraw-Hill,New York.

Knobe, J. andNichols, S. (2008). Experimental Philosophy. Oxford University Press, New York, NY.

La Porta, R., Lopez-de-Silanes, F., Shleifer, A. and Vishny, R. (1998). Law and finance. Journal of Political Economy 106, 1113-1155.

Larker, D. F. and Richardson, S.A. (2004). Fees paid to audit firms, accruals choices, and corporate governance. Journal of Accounting Research 42, 625-658.

Levitt, A. (1998). The Numbers Game'. The CPA Journal68, 14-19.

Leuz, C., Nanda, D. and Wysocki, P.D. (2003). Earnings management and investor protection. An internationalComparison. Journal of Financial Economics 69, 505-527.

Lev, B. and Thiagarajan, S.R. (1993). Fundamental Information Analysis. Journal of Accounting Research 31(2), 190-215.

Lin, B., Lu, R.and Zhang, T. (2012). Tax-induced earnings management in emerging markets: Evidence from China. The Journal of the American Taxation Association 34(2), 19-44.

Loebbecke, J.K., Eining, M.M.and Willingham, J.J. (1989). Auditor's experience with material irregularities: Frequency, nature, and detectability. Auditing: A Journal of Theory and Practice9(1), 1-28.

Loomis, C.J. (1999). Lies, Damned Lies, and Managed Earnings. Fortune140, 74-92.

Lucas, N. (2004). An interview with United States Senator Paul S. Sarbanes. Journal of Leadership and Organizational Studies11, 3-8.

MacIntyre, A. (1981). After Virtue. Duckworth \& Co., London.

Marsh, C. (2013). Business Executives' Perceptions of Ethical Leadership and Its Development. Journal of Business Ethics 114(3), 565-582. 
Merchant, K.and Rockness, J. (1994). The ethics of managing earnings: An empirical investigation. Journal of Accounting and Public Policy13(1), 79-94.

McNichols, M., Wilson, G. P. and DeAngelo, L. (1988). Evidence of earnings management from the provision for bad debts. Journal of Accounting Research 26, 1-40.

Melé, D. (2009). Business Ethics in Action. Seeking Human Excellence in Organizations (pp. 189-191).Palgrave-MacMillan, New York.

Merchant, K. A. and Rockness, J. (1994). The Ethics of Managing Earnings: An Empirical Investigation. Journal of Accounting and Public Policy13(1), 79-94.

Mulford, C. W. and Comiskey, E.E. (2002). The financial numbers game: detecting creative accounting practices.Wiley,New York.

Ojah, K. and Manrique, J. (2005). Determinants of corporate debt structure in a privately dominated debt market: a study of the Spanish capital market. Applied Financial Economics, $15,455-468$.

Parfet, W. U. (2000). Accounting Subjectivity and Earnings Management: A Preparer Perspective'. Accounting Horizons14, 481-488.

Pindado, J. and De la Torre, C. (2006). The role of investment, financing and dividend decisions in explaining corporate ownership structure: empirical evidence from Spain. European Financial Management 12(5), 661-687.

Rawls, J. (1972). A theory of justice.Oxford University Press, Oxford.

Revsine, L. (1991). The Selective Financial Misrepresentation Hypothesis. Accounting Horizons, December, 16-27.

Ronen, J.and Yaari, V. (2008). Earnings Management: Emerging Insights in Theory, Practice, and Research. Springer Science + Business Media, LLC, New York, NY.

Rubin, J.D. (2012). Fairness in business: Does it matter, and what does it mean? Business Horizons 55(1),11-15. 
Schilit, H. M. (2010). Financial Shenanigans: How to Detect Accounting Gimmicks and Fraud in Financial Reports. McGraw-Hill, UK.

Schipper, K. (1989). Commentary on earnings management. Accounting Horizons 3(4), 91102.

Shafer, W.E. (2013). Ethical Climate, Social Responsibility, and Earnings Management. Journal of Business Ethics,1-18.

Siegel, J. G. (1991). How to Analyze Businesses, Financial Statements, and the Quality of Earnings. Prentice Hall,2nd edition. New Jersey.

Solomon, R.C. (1993). Corporate roles, personal virtues: an Aristotelian approach to business ethics'. in E.R.Winkler \& J.R. Coombs (Eds.). Applied ethics: a reader (pp. 201-221). Blackwell, Oxford. Originally published in Business Ethics Quarterly 2(3), 1992, 317-330.

Stolowy, H. and Breton, G. (2004). Accounts manipulation: a literature review and proposed conceptual framework. Review of Accounting and Finance 3, 5-65.

Sun, J., Guoping, L. and George, L. (2011). Does female directorship on independent audit committees constrain earnings management? Journal of Business Ethics 99(3), 369-382.

Thomas, J. K. and Zhang, H. (2002). Valuation relevant properties of smoothed earnings. Working paper, Columbia Business School.

Vinciguerra, B. and O'Reilly-Allen, M. (2004). An examination of factors influencing managers' and auditors' assessments of the appropriateness of an accounting treatment and earnings management intentions. American Business Review22(1), 78-87.

Watts, R. L. and Zimmerman, J.L. (1986). Positive accounting theory.Prentice Hall,Englewood Cliffs, New Jersey.

Williams, B. (1985). Ethics and the Limits of Philosophy. Harvard University Press, Cambridge, MA.

Yongtao, H. and Andersen, M.L. (2011). The relationship between corporate social 
responsibility and earnings management: An exploratory study. Journal of Business Ethics 104(4), 461-471. 